Zagazig J. Agric. Res., Vol. 46 No. (6A) 2019

http:/www.journals.zu.edu.eg/journalDisplay.aspx?Journalld=1\&queryType=Master

\title{
EFFCIENCY OF SOME BIOLOGICAL AND CHEMICAL TREATMENTS AGAINST WHEAT ROOT AND CROWN ROT DISEASE
}

\author{
Ahmed M. El-Enany, Entsar E.A. Abbas, M.A. Zayed and M.M. Atia* \\ Plant Pathol. Dept., Fac. Agric., Zagazig Univ., Egypt
}

Received: 22/07/2019; Accepted: 02/09/2019

\begin{abstract}
Fusarium culmorum (W.G. Smith) Sacc., Bipolaris sorokiniana (Sacc.) Shoemaker, Rhizoctonia oryzae Kühn and Fusarium spp. were isolated from wheat plants exhibiting typical root and crown rot symptoms from different districts at Sharkia Governorate, Egypt during 2015/ 2016 growing season. Pathogenicity test revealed that $B$. sorokiniana was the most virulent one causing preemergence damping-off followed by Fusarium culmorum. In addition, F. culmorum was the most virulent one responsible for post-emergence damping-off incidence. Rhizoctonia oryzae showed the highest percentage of root rot, Moreover, F. culmorum and B. sorokiniana showed the highest percentage of disease incidence. In the same trend, $F$. culmorum induce the highest percentage of disease severity. In vitro, Trichoderma sp. bio-agent and its culture filtrate were the most effective treatment that reduced mycelial growth of the tested fungi. In vivo, it decreased pre and postemergence damping off, root rot, disease incidence and disease severity compared with the control. In addition, the obtained results indicated a significant increase on healthy survival plants and significantly improved the plant growth parameters i.e. fresh and dry weights of shoots and roots, plant height, spike length and 1000 grain weight. In vitro, Score and Amistar-top fungicides were the most effective in inhibiting the mycelial growth of $R$. oryzae followed by Amistar-top on B. sorokinana and Score on $F$. culmorum. Score was the most effective treatment revealed the highest percentage of healthy survival plants followed by Amistar-top and gave the highest protection against root and crown rot disease as shown by disease incidence and severity percentages.
\end{abstract}

Key words: Wheat, root rot, crown rot, biological control, chemical control.

\section{INTRODUCTION}

Wheat (Triticum aestivum L.) is one of the most important cereal crops grown worldwide and in Egypt. Fusarium graminearum and $F$. culmorum were the causal agent of root rot, crown rot and stem base disease in wheat (Winter et al., 2019). Fusarium spp. caused the two major diseases, fusarium head blight (FHB) and fusarium crown rot (FCR) on wheat that reduce yield qualitative and quality damage in addition to, a major mycotoxin procedure such as deoxynivalenol, zearalenone and nivalenol (Matny, 2015; Mahmoud, 2016). Paulitz and Schroeder (2016) reported that Rhizoctonia oryzae caused wheat and barley root rot, reduced emergence of wheat, moreover, reduced length and number of roots. Bipolaris sorokiniana is a pathogen of cereals including, seedling blight, root rot, black point on grains, foliar spot, blotch, leaf blight and head blight on barley and wheat. It considered as seed borne fungi transmitted with seed (Burlakoti et al., 2013; Raza et al., 2014; Somani et al., 2019). Genus Streptomyces had high inhibition effect on Fusarium spp., in vitro, as well in vivo. It reduce root rot and crown colonization by $F$. culmorum, $F$. pseudograminearum. Results reported by Winter et al. (2019) significantly reduced fusarium crown rot symptoms on roots and fresh weight and plant biomass compared with soil enrichment by Streptomyces. Streptomyces spp. used as bio-fertilizers in several crops due to their ability to promote

\footnotetext{
*Corresponding author: Tel. : +201025238311

E-mail address: usamaatia2@yahoo.com
} 


\section{El-Enany, et al.}

plant growth and biocontrol of various phytopathogenic fungi and bacteria as a reason of it is metabolizes, antibiotics and produce organic compounds in soil (Vurukonda et al., 2018). Clearly significant effect of actinomycetes were detected on $F$. culmorum, seedling growth and seed germination of wheat compared with commercial fungicide tebuconazole (Laid $\boldsymbol{e t} \boldsymbol{a l}$., 2016). Trichoderma harzianum, $T$. viens and $T$. virdi reduced mycelial growth of Bipolaris sorokiniana in dual culture method, as well as, significantly reduced disease severity, increased seed germination, plant height, dry fresh weight of root, shoot and increase 1000 grain weight (El-Gremi et al., 2017; Singh et al., 2018). Trichoderma spp. as a seed treatment reduced $F$. graminearum and $F$. culmorum root rot severity based on antagonistic activity against mycelium by mechanisms of mycoparasitism, antibiosis and chitinase encoding gene (Matarese et al., 2012; Xue et al., 2017). Trichoderma harzianum inhibited $R$. solani mycelium in vitro through dual culture technique (Rajendraprasad et al., 2017). Inoculate wheat plant with Trichoderma sp. as a seed and root treatments, reduced infection with Rhizoctonia sp., increased plant height and number of roots (Barnett et al., 2017). Seed coating treatment by plant growth-promoting rhizobacteria (PGPR) like Bacillus sp. and Pseudomonas sp., controlled wheat root and crown rot and increased significantly root length, root fresh weight, dry weight and shoot length (Moussa et al., 2013). Zhao et al. (2014) found that Bacillus subtilis isolated from wheat grains have antagonistic activity against $F$. graminearum mycelial growth, sporulation and toxin production as reason of destroying cell structure organelles and cytoplasm followed by cell death due to antifungal activity associated with production of chitinase and surfactins. Balah et al. (2018) reported that antifungal activity of some rhizobacterial isolates metabolites of Bacillus cereus and Pseudomonas geniculata were the most efficient isolates could be used as a good element to control Bipolaris sorokiniana in plant root rot disease. Bacillus sp. and Pseudomonas sp. were effective as biocontrol agent in vitro against $F$. culmorum, controlling fusarium head blight and reduced mycotoxin contamination on wheat (Dal Bello et al., 2002; Palazzini et al., 2016; Dweba et al., 2017; Mnasri et al., 2017). Pseudomonas spp. isolated from soil were active against wheat root rot disease caused by $R$. solani and $R$. oryzae, it increased seedling root and shoot length (Mavrodi et al., 2012).

Triazoles group such as Teubeconazole and Prothioconazole was the most effective fungicide for management Fusarium spp., F. culmorum, F. graminearum, $F$. cerealis and fusarium head blight of wheat. These group influence on ergosterol biosynthesis and considered most effective fungicide (Hellin et al., 2017; Shah et al., 2018). Also, Azole group of fungicides tebuconazole, prothioconazole, propiconazole and strobin (azoxystrobin) fungicides treatment showed increasing grain germination, plant height and decreased disease severity (\%) caused by $F$. culmorum and Cochlibolus sativus in addition, inhibiting their mycotoxin production (Sooväli et al., 2017; Koycu, 2019). Score fungicides (Difenoconazole) was the best performance to inhibit Drechslera sorokiniana mycelial growth in poisoned food technique and seed treatment followed by Amistar-top (Azoxystropin + Difenoconazole) as mentioned by Mehboob et al. (2015).

Propiconazole as one of azole fungicides group used widely, its targets were the demethylase enzymes involved and inhibiting the biosynthesis of sterols which building blocks of fungal cell membranes. Propiconazole at 0.1 and $0.05 \%$ after 7 days was the most effective one for inhibition mycelial growth of Cochliobolus sativus and B. sorokiniana (Kavita et al., 2017; Somani et al., 2019). Tebuconazole and Difenoconazole as active ingredient were the most effective fungicide as seed treatment with a dose of $2.5 \mathrm{~g}$ and $1.0 \mathrm{ml} / \mathrm{kg}$ wheat grains, respectively and significantly increased the seedling emergence caused by $B$. sorokiniana and Fusarium sp., as compared with control. Moreover, reduced the number of rotted roots and healthy grains per spike and yield (Shahbaz et al., 2018). Propiconazole inhibited mycelium growth of $R$. solani (Rajput et al., 2016). Also, difenoconazole and azoxystrobin as new combination fungicide was effective against $R$. solani and $R$. oryzae (Bhuvaneswari and Raju, 2012; Kucharska et al., 2018).

Thus, this work was designed to isolate the causal pathogens of wheat root and crown rot. In addition, pathogenicity test, biological and chemical control treatment of the isolated pathogens and its effect on plant growth parameters. 
Zagazig J. Agric. Res., Vol. 46 No. (6A) 2019

\section{MATERIALS AND METHODS}

\section{Samples Collection}

Naturally infected wheat plants with root samples exhibit typical symptoms doubted to be due to root rot disease were collected from different districts at Sharkia Governorate (Zagazig, Kafr El-Hamam, Ghazala and AbuKaber). Samples were transferred under cooling using ice box to Plant Pathology Lab. Plant Pathology Dept., Fac. Agric., Zagazig Univ., Egypt.

\section{Isolation and Purification of the Pathogenic Fungi}

The infected wheat roots were surface sterilized in $1 \%$ sodium hypochlorite solution for 2 minutes, rinsed twice in sterilized distilled water, dried between two sterilized filter papers. Then were cut into small pieces and transferred into water agar (WA) medium (Parsons and Munkvold, 2012) and incubated at $27 \pm 1^{\circ} \mathrm{C}$ for 7 days.

The developed fungi were recorded as frequency percentage for all the isolates and purified using the hyphal tip and/or single spore techniques (Skidmore and Dickinson, 1976; Dhingra and Sinclair, 1995). The purified fungi were transferred to potato dextrose agar (PDA) medium and kept slant at $5^{\circ} \mathrm{C}$ for identification and further studies.

\section{Detection of the Isolated Fungi}

The isolated fungi from infected wheat samples were microscopically identified according to the morphological features of mycelia and asexual spores using the description of Nelson $\boldsymbol{e t}$ al. (1983), Leslie and Summerell (2006) for Fusarium sp. and Manamgoda et al. (2014) for Bipolaris sorokiniana. The selected three isolates were identified at Plant Pathology Lab. Plant Pathology Dept., Fac. Agric., Zagazig Univ., Egypt.

\section{Pathogenicity Tests}

Pathogenicity tests of four identified isolates of Fusarium culmorum, Fusarium spp., Rhizoctonia oryzae and Bipolaris sorokiniana were carried out under greenhouse conditions at Fac. Agric., Zagazig Univ.

\section{Inoculum preparation}

Inoculum of Fusarium spp., F. culmorum, $R$. oryzae and $B$. sorokiniana prepared using autoclaved wheat grains (200 g of wheat grains, $80 \mathrm{ml}$ distilled water per flask $500 \mathrm{ml}$ ) singly inoculated by each pathogen and incubated at $27 \pm 1^{\circ} \mathrm{C}$ for three weeks (Chekali et al., 2011).

\section{Pots and soil disinfestation}

Sterilized plastic pots $(25 \mathrm{~cm}$ in diameter) with formalin $3 \%$ for $10 \mathrm{~min}$. were filled with $6.6 \mathrm{~kg}$ sterilized autoclaved sandy clay soil (1:1).

\section{Soil infestation}

Soil infestation was carried out by adding the fungal inoculum $(5 \mathrm{~g} / \mathrm{kg}$ soil) to the sterilized autoclaved soil. The infested soil was watered as usual and left for 10-15 days before sowing to stimulate the fungal growth and ensure its distribution in the soil. Control pots were treated in the same way using pathogen free autoclaved wheat grains described by El-Sayed (1999). Wheat grains Masr 1 cultivar were obtained from Filed Crop Research Institute, Agric. Res., Cent. (ARC). Grains were sterilized with $1 \%$ sodium hypochlorite solution for 2 minutes and sown at the rate of 10 grains /pot. Three replicates were used for each treatment. Inoculated fungi were re-isolated from the infected plants to confirm Kock's postulate.

\section{Disease Assessment}

Damping-off incidence was recorded as percentage of pre, post-emergence healthy survivals percentage at 15,30 and 45 days after sowing, respectively. Crown and root rots severity was done on infected plants damping off mature plants. Infected plants were removed from pots, then washed and disease severity was rated on a 0 to 3 scale based on symptoms observed on the crown and roots, 0: no symptoms (healthy roots and crown); 1: browning on the crown; 2: extension of browning to roots and 3: dark brown color of the crown and all roots. Disease severity was averaged among the replicates according to Chekali et al. (2011). Disease severity was calculated using the scale values, as follows: 


\section{El-Enany, et al.}

( $\sum$ (number of plants in a disease scale category $x$ disease scale category)/(total number of plants $\times$ maximum disease scale category) $) \times 100$ ). The most virulent isolate was selected on the basis of disease severity averages.

\section{Plant Growth Parameters}

Growth parameters including plant height $(\mathrm{cm})$, fresh and dry weights (gram) were estimated at the end of experiment. Root system was tapped out of the pot and washed with gentle stream of water, for obtaining fresh and dry weight, the roots were pressed gently between two pads of blotting paper then the fresh weight was recorded using electronic balance. Dry weight was recorded after drying the roots and shoots in oven under $70^{\circ} \mathrm{C}$ for several days until the constant weight. Spike length $(\mathrm{cm})$, spike number and weight of the 1000 kernels (gram) were determined.

\section{Biological Control}

Plant growth promoting rhizobacteria (PGPR) isolates was obtained through isolation of biocontrol microorganisms from wheat rhizosphere by the serial dilution agar plating method using different selective media according to Jacobs and Gerstein (1960). Identification of isolated Fungi, Streptomyces and bacteria was carried out at Plant Pathology Lab. Plant Pathology Dept., Fac. Agric., Zagazig Univ., Egypt using identification roles mentioned by Shirling and Gottlieb (1966); Lelliott and Stead (1987) and Krishna et al. (2012).

\section{Laboratory Experiments}

Evaluation the inhibitory effect of isolated bacteria on pathogenic fungi using dual culture technique

Antagonistic activities of identified Streptomyces sp., Bacillus sp., Pseudomonas sp. and Trichoderma sp. were done against wheat root rot pathogens were cultured for 7 days onto PDA medium, then $5 \mathrm{~mm}$ disc of the pathogenic fungi were re-cultured onto one side of $9 \mathrm{~cm}$ Petri dish and the opposite side was cultured with one disc Trichoderma sp. bioagent and/ or streak in the case of bacteria and Streptomyces sp. at the same. Three plates were used as replicates for each treatment. Mycelial discs $(5 \mathrm{~mm})$ of diameter removed from the growing edge of $R$. oryzae, $F$. culmorum and $B$. sorokiniana grown onto PDA were used as control. The plates were incubated at $28 \pm 2{ }^{\circ} \mathrm{C}$ for 5 days in the dark. Linear growth of pathogenic fungi was measured, when the control dishes reached full growth and the growth diameter average, was calculated. The inhibition rate of tested bio-agent on mycelial growth pathogens was calculated using the following formula: growth inhibition rate $(\%)=$ (Rc-Rt)/RC $\times 100$, where $\mathrm{Rc}$ is the average linear growth of pathogen (control), and Rt is the average growth of the pathogen. Four Petri dishes for each antagonist were used (Skidmore and Dickinson, 1976).

\section{Influence of antagonist bio agents culture filtrates on wheat root rot pathogen}

Antagonist cultures were grown in flasks $(250 \mathrm{ml})$ containing $100 \mathrm{ml}$ potato dextrose broth (PDB) for one week at $25^{\circ} \mathrm{C}$., nutrient agar (NA) used for bacteria and starch nitrate (SN) media for actinomycetes. Pseudomonas sp. and Bacillus sp. increased the turbidity (silkiness or cloudiness). The liquid cultures were filter sterilized using G3 filter to give sterile and cell free culture filtrate according to Jacobs and Gerstein (1960). Culture filtrates were mixed with autoclaved PDA media before solidifying (at $1 \%$ ) and poured in Petri plates. Then plats were inoculated with a disc $(0.5 \mathrm{~cm}$ diameter $)$ of the pathogens and incubated at $25^{\circ} \mathrm{C}$ for one week. Inhibition of mycelial growth of $F$. culmorum, $R$. oryzae and B. sorokiniana were calculated.

Biological control using isolated plant growth promoting microorganism's against wheat root rot and growth parameter under greenhouse conditions

In planta, healthy wheat grains cv. Masr 1 were surface sterilized in $1 \% \mathrm{NaOCl}$ (Sodium hypochlorite) for 2 minutes and then rinsed three times in sterile water to get rid of surface seed secondary fungal pathogens as mentioned by Parsons and Munkvold (2012). Then wheat grains cv. Masr-1 were soaked in $50 \mathrm{ml}$ suspension of Trichoderma sp. at $1.50 \times 10^{-6}$ spores $/ \mathrm{ml}$ for $2 \mathrm{hr}$. Wherever, in case of bacterial bioagent (Pseudomonas sp., Bacillus sp. and Streptomyces sp.) wheat grains were dipped in $50 \mathrm{ml}$ suspension at $6 \times 10^{-8} \mathrm{cfu} / \mathrm{ml}$ for 2 hr. (Ma et al., 2008). 
Zagazig J. Agric. Res., Vol. 46 No. (6A) 2019

For control treatments, Grains were soaked individually with sterile water for $2 \mathrm{hr}$, in $50 \mathrm{ml}$ according to Xue $\boldsymbol{e t}$ al. (2017). Treated grains were air dried and ten grains were planted in pots $(25 \mathrm{~cm})$ containing infested and noninfested soils as control. Three pots were used for each particular treatment. Seed soaking in sterile distilled water were sown in infested and non-infested soil to serve as positive and negative control, respectively. Disease parameter and plant growth parameter were recorded as previously mentioned.

\section{Chemical Control}

Evaluation the inhibitory effect of some fungicides on the linear growth of pathogenic isolates in vitro

Three tested fungicides Score 250 EC (Difenoconazole 25\%), Amistar-top 325 SC (Azoxystrobin 20\% and Difenoconazole 12.5\%) and Topas 100 EC (Penconazole 10\%) as shown in Table 1 were obtained from Plant Pathology Lab. Plant Pathology Dept., Fac. Agric. Zagazig Univ., Egypt. Fungicides were used at different concentrations $(0.00,0.025,0.05,0.10,0.15$ and $0.20 \mathrm{ml}$ ) against $F$. culmorum, $R$. oryzae and $B$. sorokiniana using poison food technique according to Kavita et al. (2017) on potato dextrose agar (PDA) medium. Linear growth of each tested fungus was measured, when the pathogenic fungi completely covered the surface of the medium in control treatment. The radial growth of fungus in each treatment (percent growth inhibition) was calculated using the following formula. $[\mathrm{PGI}=\mathrm{C}-\mathrm{T} / \mathrm{C}] \times 100$, Where, PGI $=$ Percent growth inhibition; $\mathrm{C}=$ Linear area of test fungus in control $(\mathrm{mm})$ and $\mathrm{T}=$ Linear area of test fungus in respective treatment (mm) according to Rajendraprasad et $\boldsymbol{a l}$. (2017).

Evaluation of some fungicides against $F$. culmorum, $R$. oryzae and $B$. sorokiniana as seed treatment under greenhouse conditions

Fungicides were applied at the recommended dose $(0.025 \mathrm{ml} / \mathrm{kg}$ grains $)$. Grains of wheat was surface sterilized as mentioned before then separately mixed with the recommended dose of each fungicide. Treated grains were left to dry. Ten grains of Masr 1 cultivar planted in pots ( 25 $\mathrm{cm}$ diameter) previously infested with the pathogenic fungi as previously mentioned and irrigated after planting. The recommended rate of fertilizers was applied. The experiment was conjunctly randomized block design (RBD) with three replicates.

\section{Statistical Analysis}

All experiments were conducted in a factorial (treatments $\times$ three fungal species) a completely randomized block design with three replicates per treatment. Analyzed was carried out according to the methods described by Snedecor and Cochran (1980) using Statistic Complete 9 Program for ANOVA and LSD analysis.

\section{RESULTS AND DISCUSSION}

\section{Samples Collection}

The samples exhibit typical disease symptoms of wheat root and crown rot were collected. The disease reduced weight of grains, Infection increased in high or semi high humidity (Shah et al., 2018; Winter et al., 2019).

Also, some of pathogenic fungi such as, Rhizoctonia spp., $R$. oryzae and $R$. oryzae AG-8 consider a necrotrophic pathogen that infect wheat and barley symptoms was chronic root rot, causing pre-emergence damping off, crown roots in seedlings, stunted plants, reduced plant growth length, reduced length and number of seminal roots and bare patch decreased losses in growth and yield as well as, number of grains on spike (Paulitz and Schroeder, 2016).

\section{Isolation, Identification and Frequency of Fungi Associated with Infected Wheat Grains}

Identification the isolated fungi based on morphological characterization was used as it has been previously utilized in various other studies for Fusarium sp. and Bipolaris sorokiniana (Nelson et al., 1983; Leslie and Summerell, 2006; Manamgoda et al. 2014).

The obtained results, diagnosed fungal isolates associated with wheat root rot, as Fusarium culmorum (W.G. Smith) Sacc., Bipolaris sorokiniana (Sacc.) Shoemaker, Rhizoctonia oryzae Kühn and Fusarium equestii. 
El-Enany, et al.

Table 1. List of the tested fungicides, their active ingredients, manufacture and rate of use

\begin{tabular}{lccc}
\hline Commercial fungicide & Active ingredient & Manufacture & Rate of used (cm/100 L) \\
\hline Score 250 EC & Difenoconazole 25\% & Syngenta & 50 \\
Amistar-top 325 SC & Azoxystrobin 20\% & Syngenta & 75 \\
& Difenoconazole 12.5\% & & \\
Topas 100 EC & Penconazole 10\% & Syngenta & 25 \\
\hline
\end{tabular}

Results presented in Fig. 1 show that the most frequently isolated fungi from infected wheat root and crown samples were $R$. oryzae, F. culmorum and B. sorokiniana $(27.80,27.40$ and $21.56 \%$, respectively). $R$. oryzae was the most frequently isolate one especially from Kafr El- Hamam (53.33\%) followed by, F. culmorum in Zagazig (50.94\%). and B. sorokiniana from Abu-Kabeer (31.15\%).

Similar results were showed by Tunali et al. (2008) that frequency of the isolated fungi from crowns and roots of wheat in dryland was reported as Rhizoctonia species found in $22 \%$, F. culmorum (14\%), B. sorokiniana $(10 \%)$ and $F$. pseudograminearum (2\%). In addition, they isolated fungi from individual tillers which were B. sorokiniana $(15 \%), F$. culmorum $(13 \%)$ and F. pseudograminearum (8\%).

Also, Abdallah-Nekache et al. (2019) reported that frequency of isolated fungi from wheat crown was $68 \%$ to F. culmorum and $10 \%$ for $F$. pseudograminearum. While, isolation from head was $94.1 \%$ to F. culmorum and $5.9 \%$ to $F$. pseudograminearum.

\section{Pathogenicity Tests}

Results obtained from pathogenicity tests under greenhouse conditions in Fig. 2 reveal that significant differences were found between tested fungi. The highest percentage of preemergence damping-off was recorded with $B$. sorokiniana followed by $F$. culmorum and $R$. oryzae. Also, Fusarium culmorum produced the highest percentage of post-emergence dampingoff. $R$. oryzae showed the highest percentage of root rot followed by $B$. sorokiniana and $F$. culmorum without significant differences among them. In addition, the highest percentage of disease incidence were found in both $F$. culmorum, B. sorokiniana and $R$. oryzae. While, $F$. equestii was the lowest one. Disease severity was in the highest level in case of $F$. culmorum followed by $B$. sorokiniana and $R$. oryzae. As well, Fusarium equestii showed the highest percentage for survival healthy plants.

Similar results were obtained by Gebremariam et al. (2018) and AbdallahNekache et al. (2019) where they reported that Fusarium culmorum was the most aggressive pathogen on wheat from seedling to heading. In addition, Fusarium species infected lower stems and crown. F. culmorum, $F$. graminearum and $F$. pseudogramineaum caused sever crown rot on wheat. They found also that, Cochilibolus sativus, $F$. graminearum, $F$. culmorum and $F$. avenaceum were virulent to wheat and barley.

Fusarium sp. produced micro-conidia in colossal amounts, which are known to transmit through air to large distances, finally infecting wheat roots and crown parts of plant as mentioned by Leslie and Summerell, (2006). B. sorokiniana as a hemi-biotroph pathogen it caused symptoms i.e. seedling blight, brown to dark brown spot, foliar blotch, leaf blight, root rot and black point of wheat. It considered transmitted with seed as seed borne fungi. In addition, it affecting significantly on seed germination and head blight on barley and wheat, as well, Bipolaris sorokiniana caused rot at the sub crown internode (Al-Sadi and Deadman, 2010; Raza et al., 2014; Somani et al., 2019).

\section{Biological Control}

\section{In vitro effect of some bioagent using dual culture technique against Fusarium culmorum, Bipolaris sorokiniana and Rhizoctonia oryzae}

Results presented in Figs. 3 and 4 indicate that, the bio-agents tested significantly reduced growth of the tested pathogenic fungi i.e. 
Zagazig J. Agric. Res., Vol. 46 No. (6A) 2019

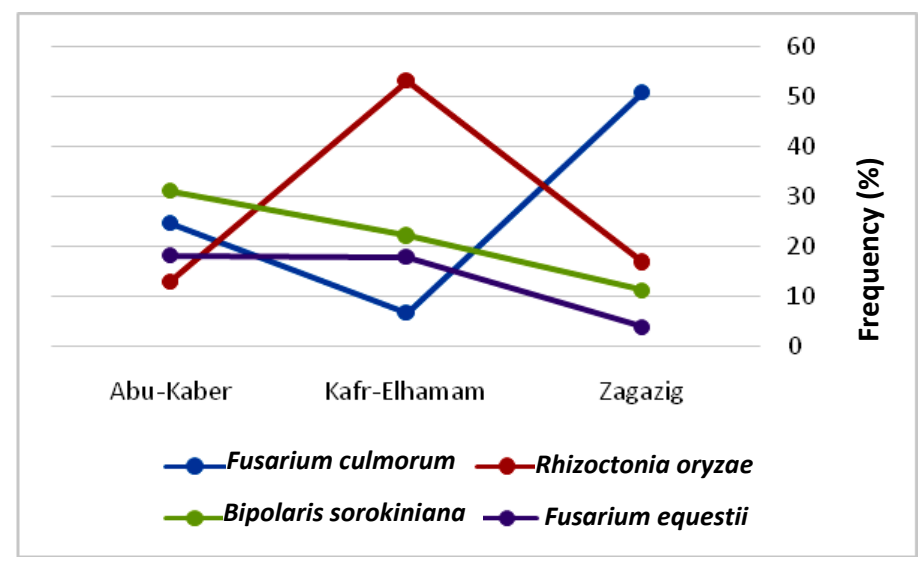

Fig. 1. Frequency of occurring isolated fungi from root and crown rot of wheat collected from different districts of El Sharkia Governorate during 2015/ 2016 growing seasons

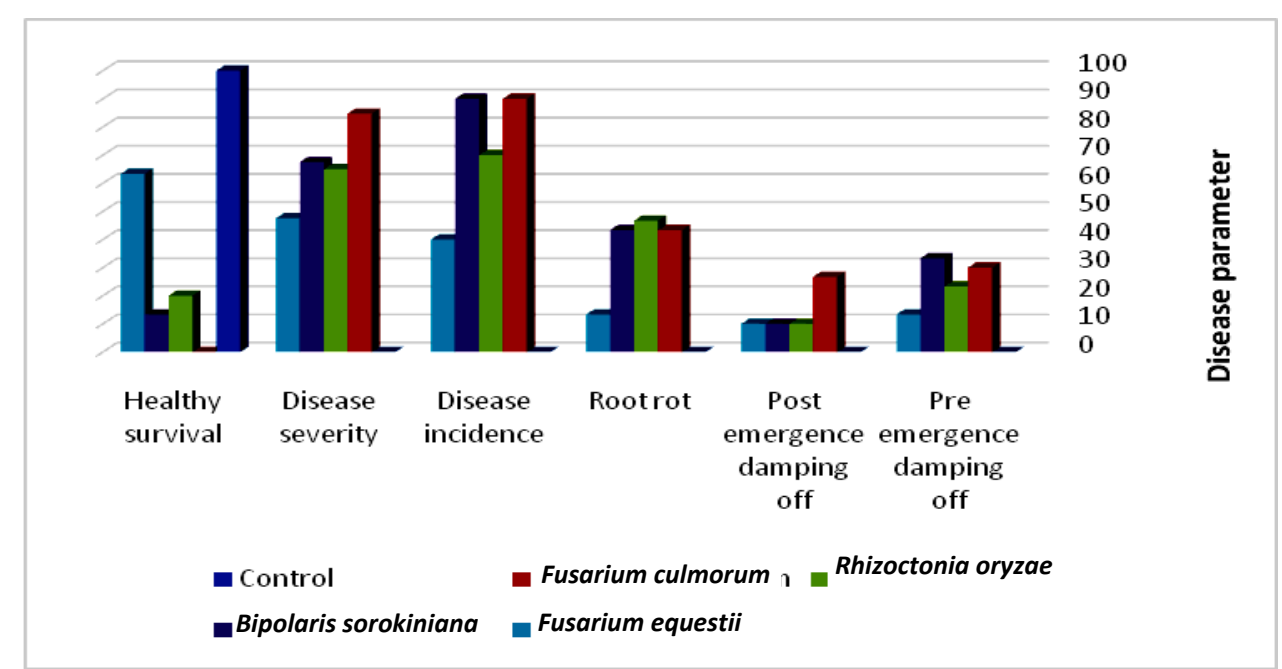

Fig. 2. Pathogenicity test for the isolated fungi that caused wheat root and crown rot disease of Masr 1 cultivar under greenhouse condition

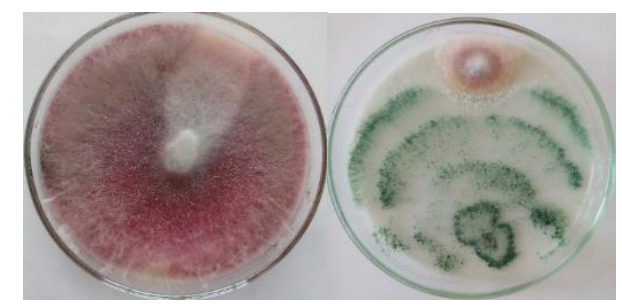

A- Trichoderma sp. against Fusarium culomrum

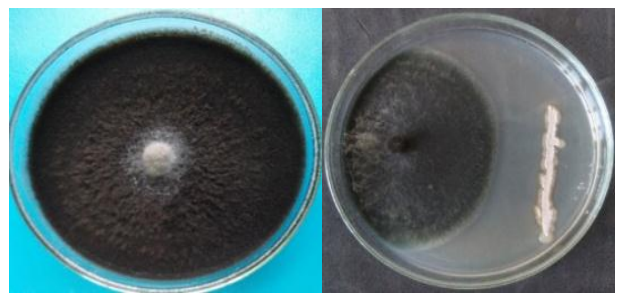

B- Streptomyces sp. against Bipolaris sorokinana

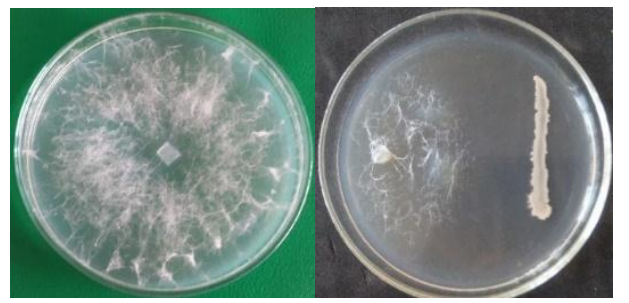

C-Bacillus sp. against Rhizoctonia oryzae

Fig. 3. Biological control using dual culture technique 
El-Enany, et al.

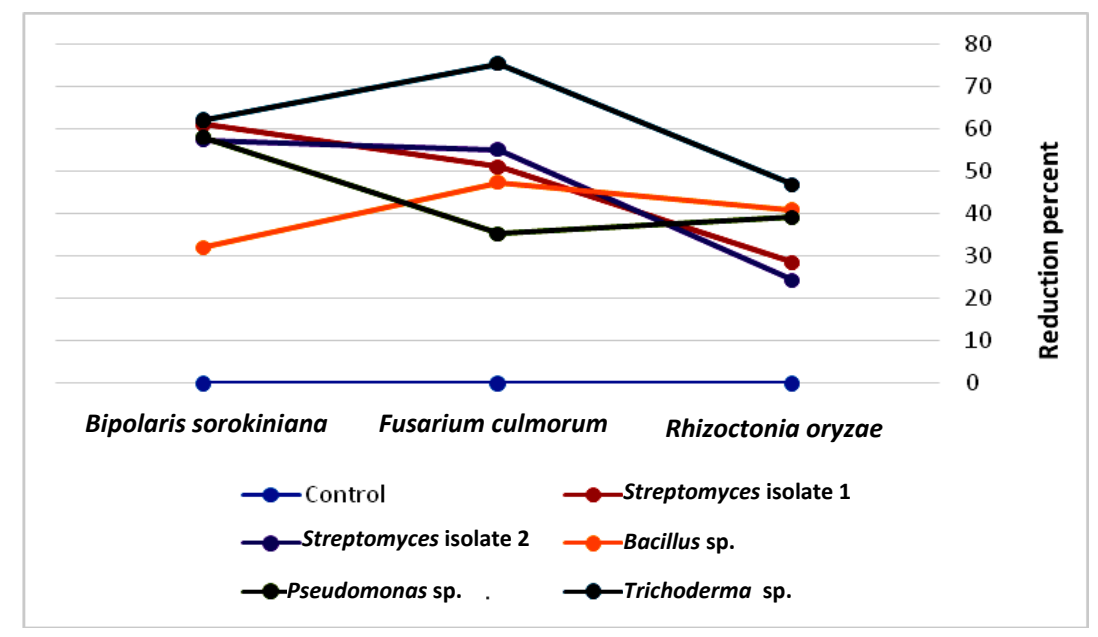

Fig. 4. Reduction percentage in the mycelial growth of the causal organisms of wheat root and crown rot disease using dual culture technique of the tested bio-agents

B. sorokiniana followed by $F$. culmorum and $R$. oryzae. Trichoderma sp. showed the highest reduction percentage of the mycelial growth of tested pathogenic fungi followed by Streptomyces isolate 1 and Streptomyces isolate 2. However, Bacillus sp. was the least effective one. In addition, Trichoderma sp. was the most effective on $R$. oryzae followed by Bacillus sp. Although, Streptomyces isolate 2 was less effective. As well, Trichoderma sp. showed the highest reduction percent followed by Streptomyces isolate 2. While, Pseudomonas sp. was the less effect one on $F$. culmorum. In case B. sorokiniana, Trichoderma sp. was the highest effective one followed by Streptomyces isolated 1. Also, Bacillus sp., was the lowest one.

\section{In vitro effect of antagonist culture filtrates against the wheat root rot pathogen}

Results in Fig. 5 show that B. sorokiniana was the highest sensitive fungus to culture filtrate followed by $F$. culmorum, while $R$. oryzae was the lowest one (50.41, 41.78 and $33.72 \%$, respectively). Trichoderma sp. culture filtrate was the most effective on reducing fungal growth followed by Bacillus sp. and Streptomyces isolate 1 (72.85, 63.63 and $43.37 \%$, respectively).

The effect of different bio-agent Streptomyces spp., Pseudomonas sp., Bacillus sp., and Trichoderma sp. on wheat root and crown rot disease and plant growth parameter under greenhouse conditions

Data in Table 2 indicate that results of both dual culture and culture filtrate were in harmony. Trichoderma sp. showed the highest percentage of healthy survival plants followed by Streptomyces isolate 1. While Pseudomonas sp. performed the lowest compared to control. There were significant differences between bioagent on pre-emergence damping off whereas, Trichoderma sp. reduced pre-emergence, followed by Streptomyces isolate 2. While, Pseudomonas sp. showed the highest percentage of preemergence, Trichoderma sp. and Streptomyces isolate 1 showed the lowest percentage of postemergence. Trichoderma sp. showed the lowest percentage of disease parameters (root rot, disease incidence and disease severity). Such results consequently followed by significant high values of plant growth parameter (Table 3). Trichoderma sp. showed the highest value of root fresh weight $(3.92 \mathrm{~g})$, shoot length $(80.00 \mathrm{~g})$ and 1000 kernel weight (48.73 g), followed by Bacillus sp. for shoot fresh weight (19.94 g) and spike length $(11.18 \mathrm{~cm})$ compared to control. Treatment of plant growth promoting rhizobacteria (PGPR) increased seed germination and shoot/ root growth might be due to IAA, gibberellins and cytokinin production. Other mechanism such as siderophores, hydrocyanic acid and induction of resistance may play a role in the mode of action of PGPR (Singh et al., 2015). Thus, rhizobacterial agents considered to be one of the most significant strategies for disease management (Laid et al., 2016). Antagonistic activity of Streptomyces against plant pathogens attained through different mechanisms, i.e. 
Zagazig J. Agric. Res., Vol. 46 No. (6A) 2019

production of secondary enzymatic activities metabolites including nutrient competition, chitinase, antibiosis, induced resistance, production of degradative enzymes, and nitrous oxide production (Cohen and Mazzola, 2006; Mahmoudi et al., 2011; Boukaya et al., 2018; Winter et al., 2019).

Streptomycetes was an active producer of volatile organic compounds and antibiotics both in soil and in planta, and this feature was helpful for antagonists of plant pathogens as biocontrol agents. Production of siderophores (ironchelating compounds) and chitinolytic enzymes as mode of action for fungal growth inhibition by endophytic actinobacteria. In addition to produce enzymes that degrade fungal cell walls by the production of chitinases. Moreover, actinomycetes present $90 \%$ of chitinolytic microorganisms (Vurukonda et al., 2018).

The biological inhibition ability of selected Pseudomonas spp. might be as reason of competition for space and nutrients, siderophore mediated competition for iron, induction of induced systemic resistance and antibiosis in the host plant (Balah and Latif, 2013). Strains of some Bacillus sp. had the ability to produce chitinolytic enzymes and to induce systemic resistance in the host plant (Tsai et al., 2002; Moussa et al., 2013). Bacillus subtilis have antagonistic activity against $F$. graminearum mycelial growth, sporulation, toxin production and reduced disease incidence by production of chitinase and surfactants and broad spectrum of antimicrobial compounds. Similar result was mentioned by Cohen- Kupiec (1998) and Zhao et al. (2014).

Balah et al. (2018) found that the secondary metabolites in case of Pseudomonas geniculata were coumaric acid, aminobutyric acid, tryptophan amino acid, 1,4-benzoquinone, succinic acid, sinapic acid and ferulic acid. However, B. cereus produced 1,4-benzoquinone, aminobutyric acid, ferulic acid benzoic acid, coumaric acids and sinapic acid. Similar result was matched with Singh et al. (2018) who found that Trichoderma harzianum, T. virdi and $T$. viens on mycelial growth of $B$. sorokiniana which increased plant height, fresh and dry weights of shoots and roots of wheat seedlings compared with the control, Moreover, the hyphal interaction between test fungus and Antagonists revealed disorganization of protoplasmic content in addition, lysis of host hyphae. Trichoderma harzianum improved germination, seedling growth, length of roots, shoots, tillers and increase 1000 grain weight in wheat disease caused by $C$. sativus and $F$. graminearum. $T$. harzianum showed hyperparasitism on the tested pathogens i.e. $F$. graminearum, $C$. sativus and A. alternata in dual culture assays (El-Gremi et al., 2017). Trichoderma isolates reduced inoculum and growth of $F$. culmorum and $F$. graminearum by mechanisms of mycoparasitism, chitinase and encoding gene antibiosis. Furthermore, it coil around the pathogens hyphae, which is considered a sign of mycoparasitism (Matarese et al., 2012).

\section{Chemical Control}

Inhibitory effect of some fungicides of tested pathogenic fungus on linear growth

Results in Table 4 show that $R$. oryzae was the most sensitive to fungicide followed by $F$. culmorum and B. sorokiniana. Also, Results showed that Score highly reduced the mycelial growth of $F$. culmorum followed by Topaz while, Amistar-top was the less effective one. No significant differences were observed between tested concentrations $(0.025,0.05,0.1$, 0.15 and $0.2 \mathrm{ml}$ ) on $R$. oryzae with both Score and Amistar-top.

Evaluation of fungicides against $\boldsymbol{F}$. culmorum,

$R$. oryzae and $B$. sorokiniana under greenhouse conditions

Results in Tables 5 and Fig. 6 indicat that Score and Amistar-top fungicides showed the lowest percentage of pre and post-emergence without significant differences between them followed by Topaz compared to control. Score showed the lowest percentage of root rot and highest percentage of healthy plants followed by Amistar-top and Topaz. There were significant differences among treatment fungicides Score, Amistar-top and Topaz in disease incidence (20.00, 22.50 and $24.53 \%$, respectively). Score showed the lowest percentage of disease severity $(8.33 \%)$ followed by Amistar-top $(14.99 \%)$. While, the highest percentage was observed with Topaz (16.57\%). 


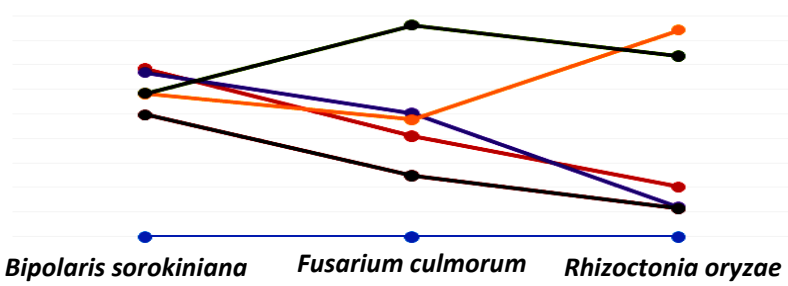

$$
\begin{array}{ll}
\longrightarrow \text { Control } & \longrightarrow \text { Streptomyces isolate } 1 \\
\longrightarrow-\text { Streptomyces isolate } 2 & \longrightarrow \text { Bacillus sp. } \\
\rightarrow-\text { Pseudomonas sp. } & \rightarrow \text { Trichoderma sp. }
\end{array}
$$

Fig. 5. Reduction percentage in the mycelial growth of the causal organisms of wheat root and crown rot disease due to culture filtrates of the tested bio-agents

Table 2. In vivo effect of some bio-agent treatments on wheat root and crown rot pathogens on

\begin{tabular}{|c|c|c|c|c|c|c|}
\hline \multirow[t]{2}{*}{ Treatment } & \multicolumn{6}{|c|}{ Pathogenic parameters } \\
\hline & Pre (\%) & $\begin{array}{l}\text { Post } \\
(\%)\end{array}$ & $\begin{array}{l}\text { Root } \\
\text { rot } \\
(\%)\end{array}$ & $\begin{array}{c}\text { Disease } \\
\text { incidence } \\
(\%)\end{array}$ & $\begin{array}{c}\text { Disease } \\
\text { severity } \\
(\%)\end{array}$ & $\begin{array}{c}\text { Healthy } \\
(\%)\end{array}$ \\
\hline Fusarium culmorum & 26.67 & 30.00 & 43.33 & 90.00 & 85.20 & 0.00 \\
\hline Rhizoctonia oryzae & 23.33 & 10.00 & 60.00 & 70.00 & 68.40 & 6.67 \\
\hline Bipolaris sorokinana & 30.00 & 10.00 & 60.00 & 90.00 & 73.33 & 0.00 \\
\hline Control & 0.00 & 0.00 & 0.00 & 0.00 & 0.00 & 100.0 \\
\hline Average & 20.00 & 12.50 & 40.83 & 62.50 & 56.73 & 26.67 \\
\hline Streptomyces isolate 1 & 0.00 & 0.00 & 0.00 & 0.00 & 0.00 & 100.0 \\
\hline Streptomyces isolate $1+$ Fusarium culmorum & 16.67 & 0.00 & 33.33 & 55.00 & 20.56 & 50.00 \\
\hline Streptomyces isolate $1+$ Rhizoctonia oryzae & 6.67 & 0.00 & 26.66 & 50.00 & 34.89 & 66.67 \\
\hline Streptomyces isolate $1+$ Bipolaris sorokinana & 6.67 & 0.00 & 16.60 & 30.00 & 18.05 & 76.67 \\
\hline Average & 7.50 & 0.00 & 19.16 & 33.75 & 18.38 & 73.34 \\
\hline Streptomyces isolate 2 & 0.00 & 0.00 & 0.00 & 0.00 & 0.00 & 100.0 \\
\hline Streptomyces isolate $2+$ Fusarium culmorum & 20.00 & 3.33 & 36.67 & 40.00 & 23.33 & 40.00 \\
\hline Streptomyces isolate $2+$ Rhizoctonia oryzae & 3.33 & 0.00 & 36.67 & 40.00 & 23.33 & 60.00 \\
\hline Streptomyces isolate $2+$ Bipolaris sorokinana & 3.33 & 3.33 & 26.67 & 40.00 & 33.33 & 66.67 \\
\hline Average & 6.67 & 1.67 & 25.00 & 30.00 & 19.99 & 66.67 \\
\hline Pseudomonas sp. & 0.00 & 0.00 & 0.00 & 0.00 & 0.00 & 100.0 \\
\hline Pseudomonas sp.+Fusarium culmorum & 23.33 & 3.33 & 33.33 & 60.00 & 23.33 & 40.00 \\
\hline Pseudomonas sp.+Rhizoctonia oryzae & 13.33 & 0.00 & 13.33 & 20.00 & 16.66 & 73.33 \\
\hline Pseudomonas sp.+Bipolaris sorokinana & 6.67 & 0.00 & 43.33 & 60.00 & 40.00 & 50.00 \\
\hline Average & 10.83 & 0.83 & 22.50 & 35.00 & 19.99 & 65.83 \\
\hline Bacillus sp. & 0.00 & 0.00 & 0.00 & 0.00 & 0.00 & 100.0 \\
\hline Bacillus sp.+Fusarium culmorum & 16.67 & 0.00 & 30.00 & 30.00 & 24.33 & 53.33 \\
\hline Bacillus sp.+Rhizoctonia oryzae & 6.67 & 0.00 & 23.33 & 30.00 & 20.33 & 70.00 \\
\hline Bacillus sp.+Bipolaris sorokinana & 13.33 & 3.33 & 33.33 & 40.00 & 30.00 & 50.00 \\
\hline Average & 9.17 & 0.83 & 21.67 & 25.00 & 18.67 & 68.33 \\
\hline Trichoderma sp. & 0.00 & 0.00 & 0.00 & 0.00 & 0.00 & 100.0 \\
\hline Trichoderma sp.+Fusarium culmorum & 13.33 & 0.00 & 13.33 & 20.00 & 10.50 & 73.33 \\
\hline Trichoderma sp.+Rhizoctonia oryzae & 3.33 & 0.00 & 23.33 & 50.00 & 33.33 & 73.33 \\
\hline Trichoderma sp.+Bipolaris sorokinana & 6.67 & 0.00 & 16.66 & 18.50 & 16.66 & 76.67 \\
\hline Average & 5.83 & 0.00 & 13.33 & 22.13 & 15.12 & 80.83 \\
\hline LSD $0.05 \%$ & & & & & & \\
\hline A- Fungi & 0.66 & 0.26 & 0.29 & & & 0.72 \\
\hline B-Bioagent & 0.54 & 0.18 & 0.47 & & & 0.85 \\
\hline C- interaction & 1.09 & 0.37 & 0.95 & & & 1.70 \\
\hline
\end{tabular}
pathogenic parameters wheat Masr1 cultivar 
Table 3. In vivo effect of some bio-agent treatments on wheat root and crown rot pathogens on plant growth parameters of wheat cultivar Masr1

\begin{tabular}{|c|c|c|c|c|c|c|c|c|c|c|}
\hline \multirow[t]{2}{*}{ Treatment } & \multicolumn{10}{|c|}{ Plant growth parameter } \\
\hline & $\begin{array}{c}\text { Root dry } \\
\text { weight (g) }\end{array}$ & $\begin{array}{c}\text { Shoot fresh } \\
\text { weight (g) }\end{array}$ & $\begin{array}{l}\text { Shoot drys } \\
\text { weight (g) }\end{array}$ & $\begin{array}{c}\text { Shoot leng } \\
\text { (cm) }\end{array}$ & $\begin{array}{l}\text { th Root length } \\
(\mathbf{c m})\end{array}$ & $\begin{array}{l}\text { Tiller } \\
\text { (No.) }\end{array}$ & $\begin{array}{c}\text { Spike } \\
\text { length }(\mathrm{cm})\end{array}$ & $\begin{array}{c}\text { Kernels } \\
\text { number (No.) }\end{array}$ & $\begin{array}{c}1000 \text { kernel } \\
\text { weight (g) }\end{array}$ & $\begin{array}{c}\text { Head } \\
\text { blight (No.) }\end{array}$ \\
\hline Fusarium culmorum & 1.15 & 12.50 & 1.24 & 68.00 & 12.00 & 2.00 & 8.90 & 39.67 & 25.70 & 2.00 \\
\hline Rhizoctonia oryzae & 1.65 & 15.27 & 4.13 & 73.00 & 14.00 & 2.00 & 9.40 & 35.33 & 37.80 & 0.00 \\
\hline Average & 1.46 & 14.91 & 3.74 & 72.25 & 14.00 & 2.25 & 9.75 & 41.00 & 36.48 & 0.50 \\
\hline Streptomyces isolate 1 & 2.43 & 18.30 & 7.03 & 79.00 & 18.00 & 3.00 & 10.87 & 59.67 & 48.10 & 0.00 \\
\hline Streptomyces isolate $1+$ Fusarium culmorum & 2.07 & 17.18 & 5.95 & 76.00 & 16.00 & 3.00 & 10.50 & 49.00 & 45.70 & 0.00 \\
\hline Streptomyces isolate $1+$ Rhizoctonia oryzae & 1.76 & 16.03 & 5.10 & 76.00 & 16.00 & 3.00 & 10.33 & 47.00 & 44.20 & 0.00 \\
\hline Average & 2.11 & 17.37 & 6.19 & 77.00 & 16.75 & 3.00 & 10.63 & 53.17 & 46.45 & 0.00 \\
\hline Streptomyces isolate 2 & 2.68 & 19.21 & 7.68 & 79.00 & 18.00 & 3.00 & 10.87 & 56.33 & 47.80 & 0.00 \\
\hline Streptomyces isolate $2+$ Fusarium culmorum & 2.54 & 17.63 & 6.74 & 77.00 & 16.00 & 3.00 & 10.67 & 50.67 & 45.80 & 0.00 \\
\hline Streptomyces isolate $2+$ Rhizoctonia oryzae & 1.61 & 15.57 & 5.11 & 76.00 & 15.00 & 3.00 & 10.27 & 44.67 & 41.10 & 0.00 \\
\hline Streptomyces isolate $2+$ Bipolaris sorokinana & 2.62 & 18.00 & 6.94 & 78.00 & 17.00 & 3.00 & 10.67 & 53.33 & 46.60 & 0.00 \\
\hline Average & 2.36 & 17.60 & 6.62 & 77.50 & 16.50 & 3.00 & 10.62 & 51.25 & 45.33 & 0.00 \\
\hline Pseudomonas sp. & 2.68 & 17.54 & 6.97 & 79.00 & 18.00 & 3.00 & 11.27 & 60.00 & 48.70 & 0.00 \\
\hline Pseudomonas sp.+Fusarium culmorum & 2.51 & 17.16 & 6.50 & 78.00 & 17.00 & 2.00 & 11.23 & 54.67 & 47.20 & 0.00 \\
\hline Pseudomonas sp.+Rhizoctonia oryzae & 2.57 & 17.29 & 6.64 & 78.00 & 17.00 & 3.00 & 11.10 & 57.33 & 47.90 & 0.00 \\
\hline Average & 2.56 & 17.23 & 6.64 & 78.25 & 17.00 & 2.50 & 11.03 & 56.75 & 47.55 & 0.00 \\
\hline Bacillus sp. & 3.21 & 20.74 & 9.65 & 80.00 & 18.00 & 2.00 & 11.33 & 57.33 & 50.10 & 0.00 \\
\hline Bacillus sp.+Fusarium culmorum & 2.30 & 20.33 & 6.34 & 79.00 & 17.00 & 2.00 & 11.17 & 54.67 & 49.60 & 0.00 \\
\hline Bacillus sp.+Rhizoctonia oryzae & 2.35 & 19.45 & 8.55 & 78.00 & 16.00 & 2.00 & 11.23 & 52.33 & 47.70 & 0.00 \\
\hline Bacillus sp.+Bipolaris sorokinana & 2.41 & 19.24 & 8.32 & 78.00 & 17.00 & 2.00 & 10.97 & 49.33 & 46.20 & 0.00 \\
\hline Average & 2.57 & 19.94 & 8.97 & 78.75 & 17.00 & 2.00 & 11.18 & 53.42 & 48.40 & 0.00 \\
\hline Trichoderma sp. & 3.03 & 20.83 & 9.53 & 81.00 & 18.00 & 3.00 & 11.33 & 58.33 & 51.40 & 0.00 \\
\hline Trichoderma sp.+Fusarium culmorum & 2.95 & 20.17 & 8.90 & 80.00 & 18.00 & 3.00 & 11.27 & 52.33 & 49.50 & 0.00 \\
\hline Trichoderma sp.+Rhizoctonia oryzae & 1.91 & 17.06 & 6.89 & 79.00 & 17.00 & 3.00 & 10.90 & 45.67 & 46.80 & 0.00 \\
\hline Trichoderma sp.+Bipolaris sorokinana & 2.69 & 18.74 & 7.54 & 80.00 & 18.00 & 3.00 & 11.17 & 48.67 & 47.20 & 0.00 \\
\hline Average & 2.65 & 19.20 & 8.22 & 80.00 & 17.75 & 3.00 & 11.17 & 51.25 & 48.73 & 0.00 \\
\hline Un treated & 1.87 & 18.63 & 7.29 & 78.00 & 16.00 & 3.00 & 10.60 & 46.67 & 42.90 & 0.00 \\
\hline \multicolumn{11}{|l|}{ LSD $0.05 \%$} \\
\hline A- Fungi & 0.38 & 0.60 & 0.49 & 0.49 & 0.55 & & 0.31 & 3.12 & & \\
\hline B-Bioagent & 0.39 & 0.48 & 0.43 & 0.69 & 0.66 & & 0.30 & 3.73 & & \\
\hline C- interaction & 0.78 & 0.96 & 0.87 & 1.38 & 1.32 & & 0.60 & 7.47 & & \\
\hline
\end{tabular}


Table 4. In vitro inhibitory evaluation of some fungicides on reduction percent of the treated pathogenic fungi

\begin{tabular}{|c|c|c|c|c|c|c|c|c|c|c|c|c|}
\hline \multirow[t]{2}{*}{ Concentration (ml) } & \multicolumn{4}{|c|}{ Rhizoctonia oryzae } & \multicolumn{4}{|c|}{ Fusarium culmorum } & \multicolumn{4}{|c|}{ Bipolaris sorokiniana } \\
\hline & Score & Amistar top & Topaz & Average & Score & Amistar top & Topaz & Average & Score & Amistar top & Topaz & Average \\
\hline $\mathbf{0 . 0}$ & 0.00 & 0.00 & 0.00 & $\mathbf{0 . 0 0}$ & 0.00 & 0.00 & 0.00 & $\mathbf{0 . 0 0}$ & 0.00 & 0.00 & 0.00 & $\mathbf{0 . 0 0}$ \\
\hline 0.025 & 94.44 & 94.44 & 70.78 & 86.55 & 72.22 & 62.22 & 66.00 & 66.81 & 70.78 & 88.56 & 71.89 & 77.08 \\
\hline 0.05 & 94.44 & 94.44 & 94.44 & 94.44 & 77.78 & 72.22 & 82.78 & 77.59 & 74.11 & 94.44 & 94.44 & 87.66 \\
\hline 0.1 & 94.44 & 94.44 & 94.44 & 94.44 & 88.33 & 75.56 & 84.78 & 82.89 & 87.44 & 94.44 & 94.44 & 92.11 \\
\hline 0.15 & 94.44 & 94.44 & 94.44 & 94.44 & 88.89 & 79.44 & 87.00 & 85.11 & 92.78 & 94.44 & 94.44 & 93.89 \\
\hline 0.2 & 94.44 & 94.44 & 94.44 & 94.44 & 94.44 & 85.22 & 88.56 & 89.41 & 93.89 & 94.44 & 94.44 & 94.26 \\
\hline Average & 78.70 & 78.70 & 74.76 & & 70.28 & 62.44 & 68.19 & & 69.83 & 77.72 & 74.94 & \\
\hline
\end{tabular}

LSD $0.05 \%$ A- Concentration 0.15 B-Fungi 0.10 C-Fungicides 0.10 
Table 5. Effect of fungicidal treatments on disease parameters of wheat root rot pathogens under greenhouse condition

\begin{tabular}{|c|c|c|c|c|c|c|c|c|c|c|c|c|c|c|c|c|c|c|c|c|}
\hline \multirow[t]{2}{*}{ Treatment } & \multicolumn{5}{|c|}{ Pre emergence damping off $(\%)$} & \multicolumn{5}{|c|}{ Post emergence damping off $(\%)$} & \multicolumn{5}{|c|}{ Root rot $(\%)$} & \multicolumn{5}{|c|}{ Healthy survival plants (\%) } \\
\hline & 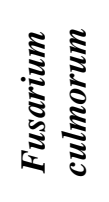 & 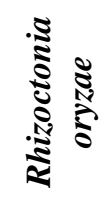 & 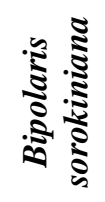 & $\begin{array}{l}\bar{e} \\
\bar{\Xi} \\
\overline{\tilde{z}}\end{array}$ & 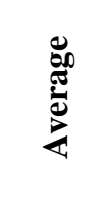 & 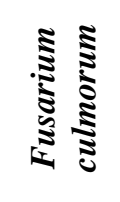 & 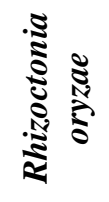 & 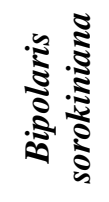 & $\overline{\bar{\Xi}}$ & 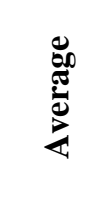 & 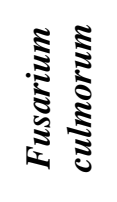 & 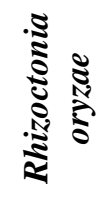 & 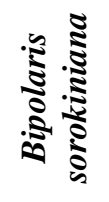 & 宊 & 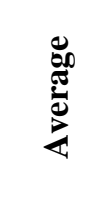 & 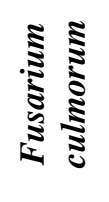 & 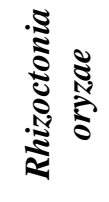 & 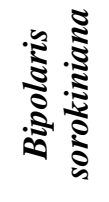 & 宊 & 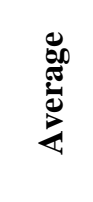 \\
\hline Without & 26.67 & 23.33 & 30.00 & $\mathbf{0 . 0 0}$ & 20.00 & 30.00 & 10.00 & 10.00 & 0.00 & 12.50 & 43.33 & 60.00 & 60.00 & 0.00 & 40.83 & 0.00 & 6.67 & 0.00 & 100.0 & 26.67 \\
\hline Score & 3.33 & 00.00 & 6.67 & 00.00 & 2.50 & 00.00 & 00.00 & 00.00 & 00.00 & 00.00 & 16.66 & 6.67 & 6.66 & 0.00 & 7.50 & 80.00 & 93.33 & 86.67 & 100.0 & 90.00 \\
\hline Amistar- top & 00.00 & 3.33 & 6.67 & 00.00 & 2.50 & 00.00 & 00.00 & 00.00 & $\mathbf{0 0 . 0 0}$ & 00.00 & 23.33 & 10.00 & 10.00 & 0.00 & 10.83 & 76.67 & 86.67 & 83.33 & 100.0 & 86.67 \\
\hline Topaz & 3.33 & 3.33 & 6.67 & $\mathbf{0 . 0 0}$ & 3.33 & 3.33 & 00.00 & $\mathbf{3 . 3 3}$ & 0.00 & 1.67 & 33.33 & 33.33 & 26.67 & 0.00 & 20.83 & 60.00 & 73.33 & 63.33 & 100.0 & 74.17 \\
\hline Average & 8.33 & 7.50 & 12.50 & 0.00 & & 8.33 & 2.50 & $\mathbf{3 . 3 3}$ & 0.00 & & 29.16 & 25.00 & 25.83 & 0.00 & & 54.17 & 65.00 & $\mathbf{5 8 . 3 3}$ & 100.0 & \\
\hline \multicolumn{21}{|l|}{ L.S.D. 0.05\% } \\
\hline A- Fungi & & 0.14 & & & & & 0.36 & & & & & 0.39 & & & & & 0.39 & & & \\
\hline B-Fungicide & & 0.41 & & & & & 0.43 & & & & & 0.63 & & & & & 0.67 & & & \\
\hline C-Interaction & & 0.83 & & & & & 0.87 & & & & & 1.26 & & & & & 1.35 & & & \\
\hline
\end{tabular}


El-Enany, et al.

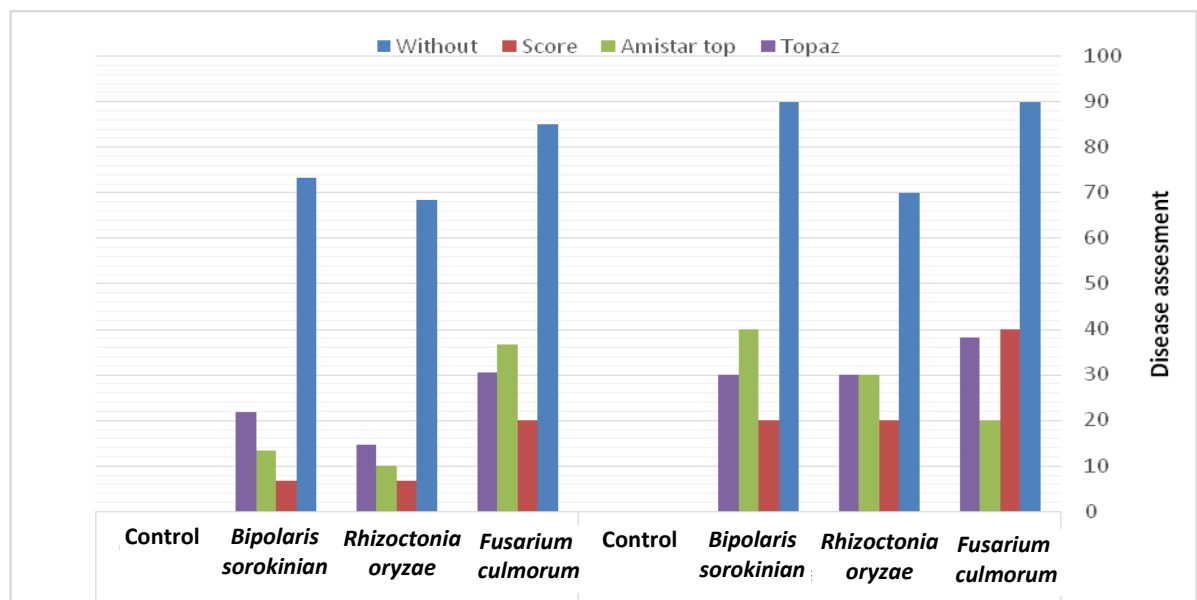

Fig. 6. Effect of fungicidal treatments on disease incidence and severity percentage of wheat root rot pathogens under greenhouse condition

Table 6. Evaluation of fungicides against $F$. culmorum, $R$. oryzae and $B$. sorokiniana under greenhouse conditions on plant growth parameters on Masr 1 cultivar

\begin{tabular}{|c|c|c|c|c|c|c|c|c|c|c|c|}
\hline \multirow[b]{2}{*}{ 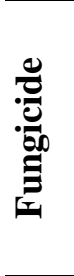 } & \multirow[t]{2}{*}{ Treatment } & \multicolumn{10}{|c|}{ Plant growth parameter } \\
\hline & & 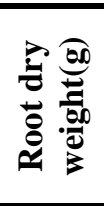 & 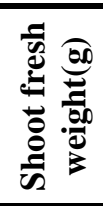 & 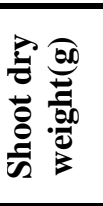 & 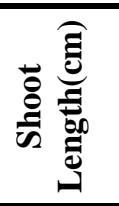 & 焉 & 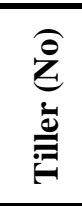 & 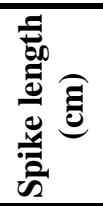 & 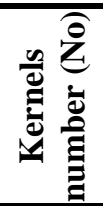 & 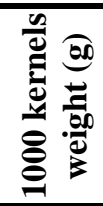 & 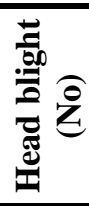 \\
\hline \multirow{4}{*}{ 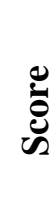 } & Control & 2.83 & 19.91 & 8.88 & 81.00 & 19.00 & 3.00 & 11.00 & 61.33 & 47.70 & 0.00 \\
\hline & Fusarium culmorum & 2.58 & 19.10 & 8.08 & 79.00 & 17.00 & 3.00 & 10.90 & 51.33 & 46.20 & 0.00 \\
\hline & Rhizoctonia oryzae & 2.64 & 19.64 & 8.64 & 79.00 & 18.00 & 3.00 & 11.10 & 54.33 & 46.70 & 0.00 \\
\hline & Bipolaris sorokinana & 2.71 & 19.65 & 8.56 & 80.00 & 18.00 & 3.00 & 11.23 & 57.00 & 47.09 & 0.00 \\
\hline & Average & 2.69 & 19.58 & 8.54 & 79.75 & 18.00 & 3.00 & 11.08 & 55.10 & 46.92 & 0.00 \\
\hline \multirow{5}{*}{ 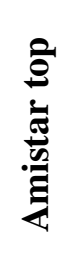 } & Control & 2.92 & 19.87 & 7.21 & 80.00 & 18.00 & 3.00 & 11.23 & 61.33 & 47.40 & 0.00 \\
\hline & Fusarium culmorum & 2.34 & 17.86 & 6.89 & 78.00 & 16.00 & 2.00 & 10.90 & 49.33 & 45.30 & 0.00 \\
\hline & Rhizoctonia oryzae & 2.65 & 19.16 & 8.47 & 78.00 & 17.00 & 3.00 & 11.03 & 56.33 & 46.50 & 0.00 \\
\hline & Bipolaris sorokinana & 2.72 & 19.38 & 8.56 & 79.00 & 17.00 & 3.00 & 11.10 & 55.67 & 46.90 & 0.00 \\
\hline & Average & 2.66 & 19.07 & 7.78 & 78.75 & 17.00 & 2.75 & 11.07 & 55.67 & 46.53 & 0.00 \\
\hline \multirow{6}{*}{ 气ै } & Control & 2.79 & 19.73 & 8.13 & 80.50 & 19.00 & 3.00 & 11.02 & 61.10 & 47.61 & 0.00 \\
\hline & Fusarium culmorum & 2.52 & 18.98 & 7.95 & 80.00 & 17.00 & 3.33 & 11.08 & 50.74 & 46.05 & 0.00 \\
\hline & Rhizoctonia oryzae & 2.54 & 19.12 & 8.52 & 79.00 & 18.00 & 3.67 & 11.12 & 56.20 & 46.21 & 0.00 \\
\hline & Bipolaris sorokinana & 2.65 & 19.41 & 8.47 & 80.00 & 18.00 & 4.00 & 11.19 & 55.59 & 47.01 & 0.00 \\
\hline & Average & 2.63 & 19.31 & 8.27 & 79.88 & 18.00 & 3.50 & 11.10 & 55.91 & 46.72 & 0.00 \\
\hline & Control & 2.84 & 19.79 & 8.14 & 80.58 & 18.00 & 3.00 & 11.14 & 61.24 & 47.52 & 0.00 \\
\hline \multirow{3}{*}{$\begin{array}{l}80 \\
10 \\
0 \\
0 \\
0 \\
0\end{array}$} & A- Fungi & 0.37 & 0.48 & 0.47 & 0.82 & 0.70 & & 0.39 & 4.68 & & \\
\hline & B-Fungicide & 0.30 & 0.79 & 0.49 & 0.66 & 0.57 & & 0.40 & 3.84 & & \\
\hline & $\mathrm{C}$-(AB) Interaction & 0.60 & 1.59 & 0.98 & 1.33 & 1.14 & & 0.80 & 7.69 & & \\
\hline
\end{tabular}


Such results consequently followed by significant high parameters of plant growth illustrated in Table 6 that, Score revealed the highest value for each of root fresh weight (3.93 $\mathrm{g})$, shoot fresh weight (19.58 g), spike length $(11.08 \mathrm{~cm})$ and 1000 grain weight $(46.92 \mathrm{~g})$, control produced, the lowest value for plant growth parameters.

Fungicides with the active substances of Tebuconazole, Propiconazole, Difenoconazole and Strobin (Azoxystrobin) groups has systemic features and commonly effectively used in the fungicide applications to seeds and leaves. These fungicides inhibit biosynthesis of ergosterol which plays an essential role in the cell membrane of the fungi and inhibiting fungal development by causing excess electrolyte loss (Akgul and Erkilic, 2016; Koycu, 2019). Moreover, it increased the germination of seeds, plant height and decreased the severity of the disease in wheat plants. Azole group, inhibited mycelial growth and reduced mycotoxin of $F$. graminearum, $F$. culmorum by affecting one or more than one places within a fungal cell (Dekker, 1982; Paul et al., 2008). Somani et al. (2019) explained propiconazole mode of action was by its inhibiting the biosynthesis of sterols of Cochliobolus sativus which building blocks of fungal cell membranes and the demethylase enzymes involved.

\section{REFERENCES}

Abdallah-Nekache, N., I. Laraba, C. Ducos, C. Barreau, Z. Bouznad and H. Boureghda (2019). Occurrence of Fusarium head blight and Fusarium crown rot in Algerian wheat: identification of associated species and assessment of aggressiveness. European. J. Plant Pathol., 154 (3):1-14.

Akgul, D.S. and A. Erkilic (2016). Effect of wheat cultivars, fertilizers, and fungicides on Fusarium foot rot disease of wheat. Turkish. J. Agric. and Forestry, 40 (1): 101-108.

Al Sadi, A.M. and M.L. Deadman (2010). Influence of seed borne Cochliobolus sativus (Anamorph Bipolaris sorokiniana) on crown rot and root rot of barley and wheat. J. Phytopathol., 158 (10): 683-690.

Balah, M.A. and H.H. Latif (2013). Biochemical alterations in wheat seedlings and some weeds related to allelopathic potential of some medicinal plants. Bulg. J. Agric. Sci., 19 (6): 1236-1246.
Balah, A.M., S.M.H. Eassa, A.E. El-Hadidy and S.A. Afiah (2018). Bioefficacy of some Rhizobactrial isolates against sorghum root rot pathogen Bipolaris sorokiniana. Acta Ecologica Sinica., 39 (11): 1872-1880.

Barnett, S., S. Zhao, R. Ballard and C. Franco (2017). Selection of microbes for control of Rhizoctonia root rot on wheat using a high throughput pathosystem. Biol. Control, 113: 45-57.

Bhuvaneswari, V. and K.S. Raju (2012). Efficacy of new combination fungicide against rice sheath blight caused by Rhizoctonia solani (Kuhn). J. Rice Res., 5 (1 and 2): 57-61.

Boukaya, N., Y. Goudjal, M. Zamoum, F. Chaabane Chaouch, N. Sabaou, F. Mathieu and A. Zitouni (2018). Biocontrol and plantgrowth-promoting capacities of actinobacterial strains from the Algerian Sahara and characterisation of Streptosporangium becharense SG1 as a promising biocontrol agent. Biocontrol Sci. and Technol., 28 (9): 858-873.

Burlakoti, R.R., S.M. Shrestha and R.C. Sharma (2013). Impact of seed-borne inoculum, irrigation, and cropping pattern on propagation of Bipolaris sorokiniana and epidemiology of foliar blight and common root rot in spring wheat. J. Plant Pathol., 95 (3):571-578.

Chekali, S., S. Gargouri, T. Paulitz, J. M. Nicol, M. Rezgui and B. Nasraoui (2011). Effects of Fusarium culmorum and water stress on durum wheat in Tunisia. Crop Prot., 30 (6): 718-725.

Cohen-Kupiec R.I.C. (1998). The molecular biology of chitin digestion. Current Opin Biotechnol., 9: 270-277.

Cohen, M.F. and M. Mazzola (2006). Resident bacteria, nitric oxide emission and particle size modulate the effect of Brassica napus seed meal on disease incited by Rhizoctonia solani and Pythium spp. Plant Soil, 286: 7586.

Dal Bello, G.M., C.I. Monaco and M.R. Simon (2002). Biological control of seedling blight of wheat caused by Fusarium graminearum with beneficial rhizosphere microorganisms. World. J. Microbiol. and Biotechnol., 18 (7): 627-636. 


\section{El-Enany, et al.}

Dekker, J. (1982). Countermeasures for avoiding fungicide resistance. Fungicide Resistance in Crop Protection, Dekker, J. and Georgipolus, S.G. (Eds.), Center for Agric. Publish. and Document., 177-178, Wageningen, 265.

Dhingra, O.D. and J.B. Sinclair (1995). Basic Plant Pathology Methods, Second Edition, Boca Raton, Florida: CRC Press. Inc., 434.

Dweba, C.C., S. Figlan, H.A. Shimelis, T.E. Motaung, S. Sydenham, L. Mwadzingeni and T.J. Tsilo (2017). Fusarium head blight of wheat: Pathogenesis and control strategies. Crop Prot., 91: 114-122.

El-Gremi, S.M., I.S. Draz and W.A.E. Youssef (2017). Biological control of pathogens associated with kernel black point disease of wheat. Crop Prot., 91: 13-19.

El-Sayed, S.A. (1999): Studies on root-rot disease of cotton in Egypt. M.Sc. Thesis, Fac. Agric., Minufiya Univ., 1-4.

Gebremariam, E.S., D. Sharma-Poudyal, T.C. Paulitz, G. Erginbas-Orakci, A. Karakaya and A.A. Dababat (2018). Identity and pathogenicity of Fusarium species associated with crown rot on wheat (Triticum spp.) in Turkey. Europ. J. Plant Pathol., 150 (2): 387399.

Hellin, P., J. Scauflaire, V. Van Hese, F. Munaut and A. Legrève (2017). Sensitivity of Fusarium culmorum to triazoles: impact of trichothecene chemotypes, oxidative stress response and genetic diversity. Pest Manag. Sci., 73 (6): 1244-1252.

Jacobs, M.J. and M.J. Gerstein (1960). Handbook of Microbiology. D.Van Nostrand Company, Inc., London.

Kavita, S., K. Pande, K.J. Yadav and Dalbeer (2017). In vitro evaluation of fungicides against Bipolaris sorokiniana causing spot blotch of barley (Hordeum vulgare L.). Int. J. Curr. Microbiol. App. Sci., 6 (10): 4734-4739.

Koycu, N.D. (2019). Effect on Fusarium culmorum of fungicides used in wheat seed. Proc. Int. Cong. Eng. and Life Sci., 593 - 601.

Krishna, K., N. Amaresan, S. Bhagat, K. Madhuri, R., C. Srivastava (2012). Isolation and characterization of Trichoderma spp. for antagonistic activity against root rot and foliar pathogens. Indian. J. Microbiol., 52(2):137-144.

Kucharska, K., B. Katulski, K. Goriewa, A. Duba and U. Wachowska (2018). Pathogenicity and fungicide sensitivity of Rhizoctonia solani and $R$. ácerealis isolates. Gesunde Pflanzen, 70 (1): 13-19.

Laid, B., K. Kamel, G. Mouloud, S. Manel, S. Walid, B. Amar and B. Faiçal (2016). Effects of plant growth promoting rhizobacteria (PGPR) on in vitro bread wheat (Triticum aestivum L.) growth parameters and biological control mechanisms. Adv. Microbiol., 6 (9): 677-690.

Lelliott, R.A. and D.E. Stead (1987). Methods for diagnosis of bacterial diseases of plants. Methods in Plant Pathology, $2^{\text {nd }}$ Ed. T.F. Preece. Blackwell Sci. Public., 216.

Leslie, J.F. and B.A. Summerell (2006). The Fusarium. Laboratory Manual. Blackwell Publishing, IA, USA, 388.

Ma, L.Y., Z. Ji, J. Bao, X. Mu, X. Li, J. Zhuang, C. Yang and Y. Xia (2008). Responses of rice genotypes carrying different dwarf genes to Fusarium moniliform and Gibberellic acid, Pl. Prod. Sci., 11 (1): 134-138.

Mahmoud, A.F. (2016). Genetic variation and biological control of Fusarium graminearum isolated from wheat in Assiut-Egypt. Plant Pathol. J., 32 (2): 145-156.

Mahmoudi, E., B.E.S. Tabatabaei and V. Venturi (2011). Virulence attenuation of Pectobacterium carotovorum using N-Acylhomoserine lactone degrading bacteria isolated from potato rhizosphere. Plant Pathol. J., 27: 242-248.

Manamgoda, D.S., A.Y. Rossman, L.A. Castlebury, P.W. Crous, H. Madrid, E. Chukeatirote and K.D. Hyde (2014). The genus Bipolaris. Studies in Mycology, 79: 221-288.

Matarese, F., S. Sarrocco, S. Gruber, V. SeidlSeibot and G. Vannacci (2012). Biocontrol of Fusarium head blight: interactions between Trichoderma and mycotoxigenic Fusarium. Microbiol., 158 (1): 98-106. 


\section{Zagazig J. Agric. Res., Vol. 46 No. (6A) 2019}

Matny, O.N. (2015). Fusarium head blight and crown rot on wheat and barley: losses and health risks. Adv. Plants Agric. Res., 2: 2-7.

Mavrodi, O.V., N. Walter, S. Elateek, C.G. Taylor and P.A. Okubara (2012). Suppression of Rhizoctonia and Pythium root rot of wheat by new strains of Pseudomonas. Biol. Control, 62 (2): 93-102.

Mehboob, S., A. Rehman, S. Ali, M. Idrees and S.H. Zaidi (2015). Detection of wheat seed mycoflora with special reference to Drechslera sorokinana. Pakistan. J. Phytopathol., 27 (1): 21-26.

Mnasri, N., C. Chennaoui, S. Gargouri, R. Mhamdi, K. Hessini, S. Elkahoui and N. Djébali (2017). Efficacy of some rhizospheric and endophytic bacteria in vitro and as seed coating for the control of Fusarium culmorum infecting durum wheat in Tunisia. European. J. Plant Pathol., 147 (3): 501-515.

Moussa, T.A., O.A. Almaghrabi and T.S. Abdel Moneim (2013). Biological control of the wheat root rot caused by Fusarium graminearum using some PGPR strains in Saudi Arabia. Ann. Appl. Biol., 163 (1): $72-$ 81.

Nelson, P.E., T.A. Tousoun and W.F. Marasas (1983). Fusarium species: An Illustrated Manual for Identification. The Pennsylvania State Univ., 193.

Palazzini, J.M., E. Alberione, A. Torres, C. Donat, J. Köhl and S. Chulze (2016). Biological control of Fusarium graminearum sensu stricto, causal agent of Fusarium head blight of wheat, using formulated antagonists under field conditions in Argentina. Biol. Control, 94: 56-61.

Parsons, M.W. and G.P. Munkvold (2012). Effects of planting date and environmental factors on Fusarium ear rot symptoms and fumonisin B1 accumulation in maize grown in six North American locations. Plant Pathol., 61: 1130-1142.

Paul, P.A., P.E. Lipps, D.E. Hershman, M.P. McMullen, M.A. Draper and L.V. Madden (2008). Efficacy of triazole-based fungicides for Fusarium head-blight and deoxynivalenol control in wheat: a multivariate metaanalysis. Phytopathology., 98 (9): 999-1011.
Paulitz, T. and K. L. Schroeder (2016). Acid soils: how do they interact with root diseases. https:// research. wsulibs. wsu. edu/xmlui/ handle/ 2376/6465.

Rajendraprasad, M., B. Vidyasagar, G.U. Devi and S.K. Rao (2017). In vitro evaluation of fungicides and biocontrol agents against Rhizoctonia solani in tomato. Int. J. Plant and Soil Sci., 17(5): 1-9.

Rajput, L.S., S.I. Harlapur, I. Venkatesh, S.K. Aggarwal and M. Choudhary (2016). In-vitro study of fungicides and an antibiotic against Rhizoctonia solani f. sp. sasakii causing banded leaf and sheath blight of maize. Int. J. Agric. Sci., (54): 2846-2848.

Raza, M., M. Hussain and M.U. Ghazanfer (2014). Characterization and pathogenicity of Biplolaris sorokiniana caused spot blotch of wheat in Pakistan. Fuuast. J. Biol., 4 (1): $97-$ 100.

Shah, L., A. Ali, M. Yahya, Y. Zhu, S. Wang, H. Si, H. Rahman and C. Ma (2018). Integrated control of Fusarium head blight and deoxynivalenol mycotoxin in wheat. Plant Pathol., 67 (3): 532-548.

Shahbaz, M., M. Riaz, S. Ali, F. Ahmad, A. Hussain, G. Nabi, M.T. Chaudhry and S. Muhammad (2018). Effect of seed dressing chemicals on emergence, yield and against soil and seed borne diseases of wheat. Pak. J. Phytopathol., 30 (2): 183-189.

Shirling, E.B. and D. Gottlieb (1966). Methods for characterization of Streptomyces species. Int. J. Syst Bacteriol., 16 (3): 313-340.

Singh, D., S.K. Pande, J.K.Y. Kavita and S. Kumar (2018). Bioefficacy of Trichoderma spp. against Bipolaris sorokiniana causing spot blotch disease of wheat and barley. Int. J. Curr. Microbiol. App. Sci., 7 (3): 2322-2327.

Singh, P., P. Singh and M. P. Singh (2015). Assessment of antifungal activity of PGPR (plant growth-promoting rhizobacterial). Int. J., 3 (10): 803-812.

Skidmore, A.M. and C.H. Dickinson (1976). Colony interactions and hyphal interference between Septoria nodorum and phylloplane fungi. Transactions of the British Mycol. Soc., 66 (1): 57-64. 


\section{El-Enany, et al.}

Snedecor, G.W. and W.G. Cochran (1980). Statistical Methods. Oxford and J.P.J. Publishing Com. $7^{\text {th }}$ Ed.

Somani, D., R. Adhav, R. Prashant and N.Y. Kadoo (2019). Transcriptomics analysis of propiconazole-treated Cochliobolus sativus reveals new putative azole targets in the plant pathogen. Functional and Integrative Genomics, 19: 453-465

Sooväli, P., M. Koppel and T. Kangor (2017). Effectiveness of seed treatment against Fusarium spp. and Cochliobolus sativus of spring barley in different conditions. Agron. Res., 15 (1): 280-287.

Tsai, G.J., W.H. Su, H.C. Chen and C.L. Pan (2002). Antimicrobial activity of shrimp chitin and chitosan from different treatments and applications of fish preservation. Fisheries Sci., 68: 170-177.

Tunali, B., J.M. Nicol, D. Hodson, Z. Uckun, O. Büyük, D. Erdurmuş, H. Hekimhan, $H$. Aktaş, M.A. Akbudak and S.A. Bağci (2008).
Root and crown rot fungi associated with spring, facultative, and winter wheat in Turkey. Plant Dis., 92 (9): 1299-1306.

Vurukonda, S.S.K.P., D. Giovanardi and E. Stefani (2018). Plant growth promoting and biocontrol activity of Streptomyces spp. as endophytes. Int. J. Molec. Sci., 19 (4): 952962.

Winter, M., P.L. Samuels, L.K. Otto-Hanson, R. Dill-Macky and L. Kinkel (2019). Biocontrol of Fusarium crown and root rot of wheat by Streptomyces isolates- it's complicated. Phytobiomes J., 3: 52-60.

Xue, A.G., W. Guo, Y. Chen, I. Siddiqui, G. Marchand, J. Liu and C. Ren (2017). Effect of seed treatment with novel strains of Trichoderma spp. on establishment and yield of spring wheat. Crop Prot., 96: 97-102.

Zhao, Y., J.N. Selvaraj, F. Xing, L. Zhou and Y. Wang (2014). Antagonistic action of Bacillus subtilis strain SG6 on Fusarium graminearum Plos One, 11 (1): 1094-1105.

\section{كفاءة بعض معاملات المكافحة الحيوية والكيميائية ضـــ مـرض عفن الجـذور والتــاج فى القـــح \\ أحمد محمد العنانى- إنتصار السيد عبد النبي عباس ـ محمد أمين عبدالمنعم زايل ـ محمود محمد عطيه

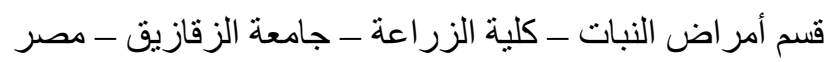

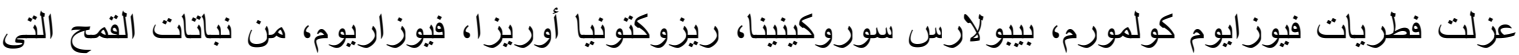

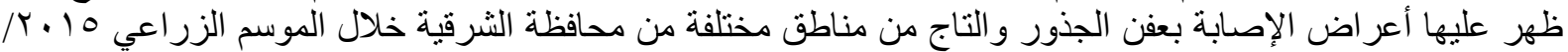

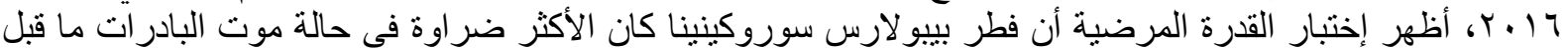

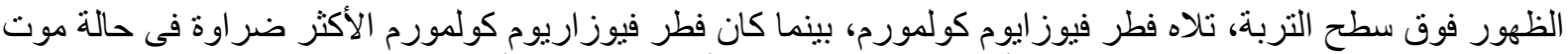

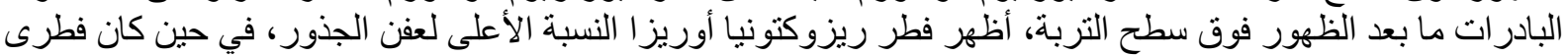

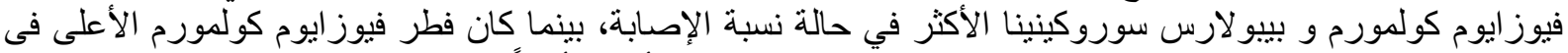

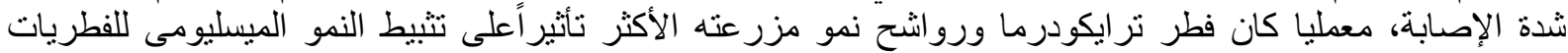

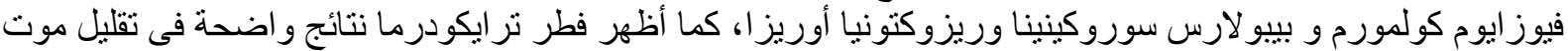

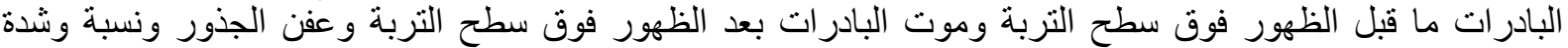

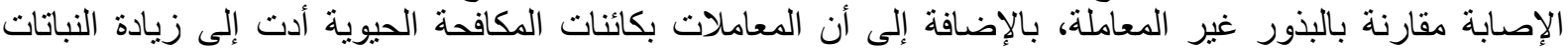

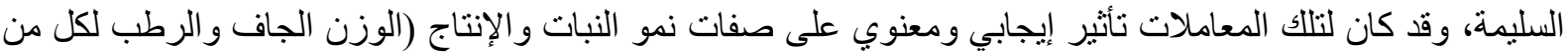

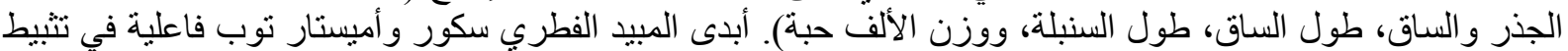

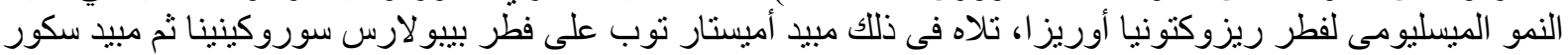

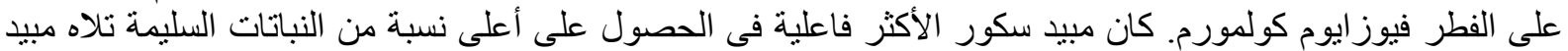

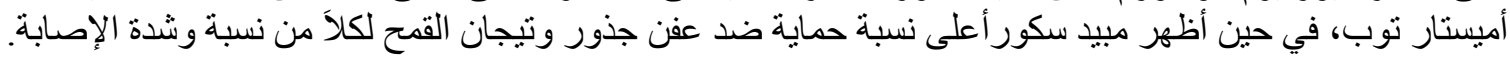

أستاذ أمر اض النبات ـ كلية التكنولوجيا و التنمية ـ جامعة الزقازيق.

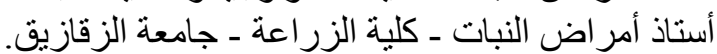

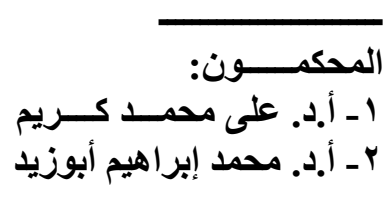

